\title{
The Jewish Contribution to Civilization Discourse: An Egyptian-Jewish Appropriation in the 1940s
}

\author{
Lucia Admiraal | ORCID 0000-0002-6993-8043 \\ Doctoral candidate, Department of History, European Studies and Religious \\ Studies, University of Amsterdam, Amsterdam, The Netherlands \\ l.r.e.admiraal@uva.nl
}

\begin{abstract}
The idea of the Jewish contribution to civilization is generally understood as a Western counter-discourse that, often expressed in response to anti-Semitism, aims to change attitudes towards Jews. My examination of the appropriation of this idea by the Egyptian-Jewish writer Alfred Yallouz in the early 1940s proposes that he embedded it in his national and regional politics of Jewish cultural reform. Here, it served the aim of promoting Jewish belonging to Arab society by addressing historical Jewish contributions to Arab culture, and connecting these to Arab-Jewish relations in the present.
\end{abstract}

\section{Keywords}

Jewish contribution - apologetics - Arabic - translation - newspapers - Middle East

\section{Cecil Roth in Arabic ${ }^{1}$}

In 1941, the Egyptian-Jewish newspaper al-Shams published an Arabic translation of The Jewish Contribution to Civilization (1938) by Cecil Roth (1899-1970), the well-known British-Jewish historian and president of the Jewish Historical Society of England. Nașib al-yahūd min al-ḥadāra, as the title of Roth's book was translated into Arabic, appeared in al-Shams as a serial over a period of

1 Research for this article was made possible by funding from the Nwo (The Dutch Research Council) within the 'PhDs in the Humanities 2016' program, project number 322-25-0o8.

(C) LUCIA ADMIRAAL, 2021 | DOI:10.1163/18750214-BJA10010

This is an open access article distributed under the terms of the CG $\mathrm{BY}_{4}$ olicense. Brill, com04/26/2023 11:13:33AM 
four years. ${ }^{2}$ The editor of al-Shams, Saad Malki ${ }^{3}$ (Sa'd Ya'qūb Mālikī) (18981988), commented on the first excerpt that he considered it 'one of the most important books of the last years,' which he decided to publish 'to serve the truth and to demonstrate the merit $(f a d l)$ that the anti-Semites $\left(a^{c} d \bar{a}^{3}\right.$ al-sāmiyya) seek to diminish. ${ }^{4}$ Although these words suggest an interest of countering anti-Semitism similar to Roth, ${ }^{5}$ I will argue that the discourse of the Jewish contribution was primarily embedded in the program of Jewish cultural reform shared by al-Shams's editor and writers and their regional network of Jewish writers of Arabic.

Roth's book had been translated by Alfred Yallouz (Alfrīd Yalūz) (1898-?), a translator at the Ministry of Agriculture in Cairo who had previously worked as the librarian of the Société Royale de Géographie during the $1920{ }^{6}{ }^{6}$ and Mansour Wahba (Manșūr Wahba), ${ }^{7}$ a lecturer at the Faculty of Engineering of Fu'ād I University in Alexandria. ${ }^{8}$ Both were frequent writers for al-Shams and involved in local Jewish cultural reform projects, such as the establishment of a reform society that called for the use of Arabic in schools, the community council, and public life by Egyptian Jews. Yallouz was the secretary of the Société d'études historiques juives d'Egypte, established in $1925,{ }^{9}$ and directed the Egyptian-Jewish youth club in Cairo, the Jam'iyyat al-Shubbān al-Yahūd al-Mișriyyīn. His translations (from English, French, and Arabic) further included the anthology A Book of Jewish Thoughts (1920) by the British chief rabbi Joseph Hertz. ${ }^{10}$ In 1936, he was a candidate for the Egyptian nationalist

2 The translation was published between 28 November 1941 and 8 June 1945 .

3 I will use the transliteration of the authors' names in this article, which they themselves used in their publications written in Latin script.

4 Al-Shams, 28 November 1941, 3.

5 C. Roth, The Jewish Contribution to Civilization (New York 1940) $\mathrm{x}$.

6 Israël, 5 and 12 February 1926, 3. Retrieved online: http://jpress.nli.org.il/ (September 2019).

$7 \quad$ So far I have not been able to find his date of birth and death.

8 Mansour Wahba translated the introduction and chapter 9, the latter under the title 'Al-yahūd wa taqaddum al-ulüm' (The Jews and the progress of the sciences). Alfred Yallouz translated the remaining eleven chapters. Little is known about Yallouz's and Wahba's personal and professional lives. I have derived their occupations as translator and lecturer respectively, from descriptions in al-Shams and al-Álam al-Isrä̀illi. Gudrun Krämer provides a brief description of the group of Egyptian Jewish patriots in which Yallouz was involved in G. Krämer, The Jews in Modern Egypt: 1914-1952 (London 1989) 169-170.

$9 \quad$ The society was modelled after the Jewish Historical Society of England, of which Cecil Roth served nine times as president. See al-Shams, 22 June 1942, 2. The Egyptian society was short-lived, but resumed its activities in the late 1940s and reissued its bulletin Revue de l'histoire juive en Égypte in 1947.

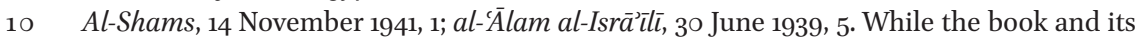
translation were discussed in the newspapers, the translation itself was not published. 
Wafd party during the local elections in the Cairo Muski Quarter where al-Shams was printed, bordering the old Jewish Quarter."

My focus in this article will be on Alfred Yallouz. His writings and translations appeared during the 1930s and 1940s in two closely connected Jewish communal newspapers: the aforesaid Egyptian-Jewish Arabic weekly al-Shams (The Sun, 1934-1948), which combined Egyptianist and cultural Zionist orientations under the banner of revival (nahda), and the Lebanese-Jewish Zionist bi-weekly in Arabic al-Ālam al-Isrä̀̄ll (The Jewish World, 1921-1948), ${ }^{12}$ presented as the organ of the Jewish communities in Lebanon and Syria. ${ }^{13}$ Al-Shams represented a rather small group of Egyptian Jewish patriots that also supported the Zionist movement without considering this a contradiction, a position that was ultimately untenable. ${ }^{14} \mathrm{Al}$-Shams's nationalist outlook of Egyptianization (tamsīi ) and Arabization (ta'rīb), and the Egyptian nationalist youth club of which Yallouz served as president, should be viewed in the context of anti-imperialism and a growing rejection of the continuing foreign and British influence in Egypt. As the majority of Jews in Egypt were foreign nationals or stateless, their presence in Egypt as mutamașșirūn (Egyptianized foreigners) became politicized as a result of growing calls for nationalization, anti-imperialism as well as growing opposition to Zionism. ${ }^{15}$ Considering the multilingual, yet predominantly francophone cultural environment in which the approximately $75, \mathrm{ooo}^{16}$ Jews in Egypt partook, the newspaper's national audience must have been fairly limited, although it also had Muslim and Christian readers. ${ }^{17}$ Though al-Shams and al-Ālam al-Isrǟill were first and foremost communal newspapers, it is viewed through a transnational lens that their discourses acquire additional meaning. The editors of both newspapers shared the aim of Jewish integration in the Arab world and Arab-Jewish rapprochement, using the Arabic language as a vehicle to this end, and targeting both Jewish and non-Jewish Arabic audiences.

11 R. Kimche, Zionism in the Shadow of the Pyramids: The Zionist Movement in Egypt: 19181948 (Tel Aviv 2009) 166 [Hebrew].

12 From 1946 until it's closing in 1948, the newspaper continued under the name al-Saläm (Peace).

13 G. Bracha, 'Al-Ālam al-Isrä̀illi. The Place of the Journal in the Jewish and Arabic Press in the Middle East against the Background of the Changes in the Syrian and Lebanese Jewish Communities, 1921-1948' (PhD diss., Bar Ilan University 2012) [Hebrew].

14 For a brief discussion of al-Shams and its writers, see Krämer, The Jews in Modern Egypt, 168-172; Kimche, Zionism in the Shadow of the Pyramids, 166-168; Victor Nahmias, “Al-Shams". A Jewish newspaper in Egypt, 1934-1948,' Pe'amim 16 (1983) 128-141 [Hebrew].

15 Krämer, The Jews in Modern Egypt, 48-49.

16 Krämer, The Jews in Modern Egypt, 4.

17 Victor Nahmias estimates that the newspaper had a circulation of 1500-2200, based on an interview he held with the editor Saad Malki in 1975. See Nahmias, “'Al-Shams," 130. 
The idea of the Jewish contribution to civilization can already be recognized as a prominent theme in both al-Shams and al-'Ālam al-Isräìlì before the publication of the translation, as it appeared in reflections on Nazi antiSemitism in Europe, as well as in relation to the topic of the revival of Jewish culture in the Arab world as part of the editors' integrationist agendas. In May 1933, the editors of al-'Alam al-Isrä'illi wrote in response to anti-Semitism in Nazi Germany: 'The world in the present day acknowledges the excellence of the Greeks and the Romans, whose culture and civilization had a great influence on the progress of Europe. But when do we hear the world acknowledge the Jewish contribution to the refinement and progress of the world?' They went on to argue that the 'Israelites' were the 'spiritual guide of the civilized peoples,' and that the principles of European civilization of 'social justice, rights and culture,' were essentially based on the Torah..$^{18}$ In both newspapers, Jews were characterized as maintainers of the monotheistic spirit and morals, by their loyalty and patriotism, and as luminaries in science and culture, while Jewish participation in the European national armies during the Great War epitomized Jewish patriotism and support for democracy. ${ }^{19}$

In December 1946, the Iraqi Jewish writer 'Bahjat S.' published a two-part article in al-Salām (Peace, 1946-1948), al-Ālam al-Isrǟillì's successor, entitled 'How the Jews benefited the world' (Mã afäda al-yahüd al-älam). The author summed up Jewish contributions to modern scientific progress, welfare, and global health, and pointed to the Jewish origins of recent inventions such as the telegraph, the phonograph, and the gramophone. ${ }^{20}$ Jewish genius is associated here with the progress of civilization as simultaneously European/Western and universal. In a later publication, however, we find the same author express the idea that Jews in the medieval world had transported (naql) civilization from the East to the West. ${ }^{21}$ The latter idea can hardly be isolated from the Arabic revival movement and its common idea that knowledge had been transported

18 Al-'Álam al-Isrä'illi, 15 May 1933, 1 . The idea of Jews as recipients and carriers of monotheism is strongly present in Cecil Roth's The Jewish Contribution to Civilization, though he was hardly the first to advance this idea. In the first chapter of his book, 'The Hebraic Heritage,' Roth discussed the Jewish monotheistic contribution to the Western world, and its 'breaking of the shackles of polytheism,' and argued that Jewish monotheism lay at the basis of Western spiritual and scientific life. See Roth, The Jewish Contribution to Civilization, 3-21, in particular $5^{-6 .}$

19 See, e.g. an account on Jewish contributions to civilization by Albert Jamal in al-'̄lam al-Isrầ' $\bar{l} \overline{\text {, }} 3$ January 1944, 6; the article 'The Arab and Jewish Contribution to Civilization,' al-Shams, 12 May 1939, 2; and an article on 'Jewish intelligence' written by Mansour Wahba in al-Shams, 15 September 1944, 4.

$20 \quad$ Al-Salām, 17 December 1946, 7.

21 Al-Salām, 25 April 1947, 6-7. 
in the past from East to West, and hence that at the roots of European progress lay eastern origins. ${ }^{22}$

In what follows, my aim is not only to show that the Jewish contribution discourse 'travelled,' and hence that it is not an exclusively Western phenomenon, but even more so how this discourse was appropriated by a regional network of Jewish cultural reformists in the Middle East. I use the metaphor of travel as to avoid the assumption of the appearance of the discourse analyzed in this study being secondary or merely a derivative from Roth's original. ${ }^{23}$ The notions of adaptation and appropriation are closely related, and not mutually exclusive, manifestations of intertextuality. The difference between them, Julie Sanders argues, lies in the extent to which the link to the source text is made explicit. An adaptation 'signals a relation with an informing sourcetext or original,' while appropriation 'frequently affects a more decisive journey away from the informing source into a wholly new cultural product and domain. ${ }^{24}$ In case of the latter, the textual relationship is less explicit and more embedded, while the political or ethical motivation that has shaped the interpretation is often inescapable. ${ }^{25}$ I will use the notion of appropriation while following Marwa Elshakry's proposal to view translation as a 'creative act,' and knowledge production as always 'socially embedded,' which allows us to look for meaning beyond the original text. ${ }^{26}$

The translation of Cecil Roth into Arabic by Yallouz and Wahba illustrates the central practice of science translations and popularizations in the period of cultural and literary production, entangled with discourses on reform and revival, which is known as the Nahda. ${ }^{27}$ The Nahda 'unfolded in translation,' Shaden M. Tageldin argues, as it transported the imperial languages of French and English into Arabic, while simultaneously reforming ('modernizing') and preserving the Arabic language. ${ }^{28}$ As their reformist contemporaries, al-Shams's writers were preoccupied with language and translation, $t a{ }^{c} \mathrm{r} b$, whereby the

22 J. Hanssen and M. Weiss, 'Introduction. Language, Mind, Freedom and Time. The Modern Arab Intellectual Tradition in Four Words,' in J. Hanssen and M. Weiss, eds., Arabic Thought Beyond the Liberal Age: Towards an Intellectual History of the Nahda (Cambridge 2016) 1-37, 32-33; M.S. Elshakry, 'Knowledge in Motion: The Cultural Politics of Modern Science Translations in Arabic,' ISIS 90, no. 4 (2018) 701-730, esp. 717.

23 J. Sanders, Adaptation and Appropriation (Abingdon 2006) 27.

24 Sanders, Adaptation and Appropriation, 12.

25 Sanders, Adaptation and Appropriation, 2, 4, 32.

26 M. Elshakry, Reading Darwin in Arabic, 1860-1950 (Chicago 2013) 18.

27 S. Sheehi, Foundations of Modern Arab Identity (Gainesville 2004); Hanssen and Weiss, Arabic Thought.

28 S.M. Tageldin, Disarming Words: Empire and the Seductions of Translation in Egypt (Berkeley 2011) 5 . 
latter term could imply both Arabization (of Jewish life) and translation into Arabic. Yallouz's and Wahba's integral translation (ta'rïb) was made at a time when the Arabic language had been profoundly transformed through language debates and reforms largely driven by the press, and the development of new styles and genres. Absent in their translation are the neologisms and transliterations that were common in 19th-century Arabic translations of foreign scientific and scholarly works. These 'borrowings' had come under increasing criticism following the British occupation of Egypt in 1882, and again after the nationalist revolution of $1919 .{ }^{29}$ The translators have remained close to Roth's original text, maintaining its structure and using the clear and concise language that had become typical of Nahda journalistic prose.

Yet an overt focus on the question of fidelity might lead to judgements about good and bad translations, which are often tied to linear narratives about translation styles in the Nahda and the development of Arabic as a 'modern' language. ${ }^{30}$ An analysis of Yallouz's and Wahba's more subtle translational choices would require a different study; I am primarily interested here in Yallouz's appropriation of Roth's discourse. What deserves to be mentioned, however, is that they added a universalist emphasis to the title of the book. The excerpts in al-Shams, over the four years in which the translation was published, carry the title Nașib al-yahüd min al-hadạra (The Jewish Contribution to Civilization, or more literally, The Jewish Share in Civilization), but also interchangeably Nașīb al-yahüd min hạdārat al-älam or Nașīb al-yahüd min hadāarat al-dunyā (The Jewish Contribution to World Civilization). This is telling because, as will be explained below, Roth's thesis was ultimately concerned with Jewish contributions to European culture, which the translators logically sought to universalize and simultaneously localize for their Arabic readership.

\section{The Jewish Contribution to Arab Culture}

The appropriation of the Jewish contribution discourse for regional Jewish projects of cultural reform and revival can be illustrated by the publication of

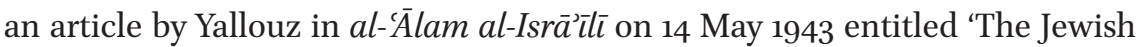
Contribution to Arab Culture' (Nașib al-yahüd fì l-thaqāfa al-'arabiyya). ${ }^{31}$ The

29 Elshakry, 'Knowledge in Motion,' 716-719.

30 Recent critiques on these linear perspectives on Arabic literature, and its accompanying traditional/modern binary, include two works that focus on fiction translations in Egypt: S. Selim, Popular Fiction, Translation and the Nahda in Egypt (Cham 2019); M. Kesrouany, Prophetic Translation: The Making of Modern Egyptian Literature (Edinburgh 2019). 
editors, Selim (Salīm) Eliyahu Mann and Moïse Adjami ('Ajamī), introduced Yallouz as 'one of the finest amongst the Egyptian Jewish youth' (though he must have been at least 42 years old at the time), whose communal intellectual projects continue to arouse 'pride and astonishment.' Later that year, they announced the publication of Yallouz's Arabic translation of Cecil Roth's The Jewish Contribution to Civilization, to enable their readers 'to study this useful book. 32 However, the publication of the translation, which would have followed its earlier appearance in al-Shams, was never realized. Although Yallouz does not mention Cecil Roth's work in his article, in what follows I hope to demonstrate that his article can be considered an appropriation of the idea of the Jewish contribution to civilization.

In the narrative that Yallouz unfolds in 'The Jewish Contribution to Arab Culture,' he refers to anti-Semitism only with reference to the European context. The enemies of the Jews, he states, perceive the latter as 'materialists, remote from the splendor of the imagination, who hold on with an iron fist to worldly matters (shu'ün dunyawiyya).' Yallouz refutes this idea, and defensively states that Jews during the Middle Ages, being constantly persecuted and forced to move from one country to another, and too helpless to devote themselves to their imagination, nevertheless accomplished much worth to be remembered. ${ }^{33}$ Here, we see Yallouz engage, as did Roth, with Western debates since the 19th century, both in its anti-Semitic versions and (philoSemitic) counterclaims, on Jewish intelligence and genius, and challenge the anti-Semitic claim that Jews lack imagination. ${ }^{34}$ The latter idea was strongly present in European philological classifications of world languages and their speakers, and the creation of an opposition between Greek and Indo-European creativity and myth making, and Semitic monotheism and rigidity. ${ }^{35}$

In Cecil Roth's preface to the 1940 edition of The Jewish Contribution to Civilization, he wrote that German anti-Semitism had urged him to write on the Jewish contribution to civilization, which was 'about Jews and not Judaism

32 Al-'̄́lam al-Isrāî̀lī, 20 August 1943, 6.

33 Al-'Álam al-Isrä̀ìli, 14 May 1943, 3.

34 The discourse of the Jewish contribution to civilization has often been criticized, not in the least by Jewish intellectuals, for its apologetics and notions of superiority. Roth was well aware of this problem, considering his statement in the introduction that 'nothing has been further from my mind than any sort of Jewish chauvinism': Roth, The Jewish Contribution, xv. See for a discussion of this tension J. Cohen and R.I. Cohen, eds., The Jewish Contribution to Civilization: Reassessing an Idea (Oxford 2008) 4, 11 and 162-164; S.L. Gilman, Smart Jews. The Construction of the Image of Jewish Superior Intelligence (Lincoln 1997) 42.

35 M. Olender, The Languages of Paradise: Race, Religion, and Philology in the Nineteenth Century (Cambridge 1992) 18. 
alone. ${ }^{36}$ In a footnote, he called the terms 'Aryan and non-Aryan' a 'scientific monstrosity.'37 Anti-Semites, Roth wrote, held that Jews were 'middle men' who have not produced anything themselves. In the book, Roth challenged such claims by discussing various domains in which Jews had excelled, such as science, religion, journalism, and medicine. The examples collected in the book showed, in Roth's view, that the Jew was 'perhaps' distinguished by 'intellectualization,' 'freshness of outlook because of his external position,' his 'faculty for synthesis', and 'for introducing new ideas.' ${ }^{38}$ Roth's general aim was to show the various ways in which Jews had contributed, throughout history, to European civilization, and hence that they were a fundamental part of it. ${ }^{39}$ A similar thesis had been expressed by Thorstein Veblen two decades earlier in 'The Intellectual Pre-Eminence of Jews in Modern Europe,' where he explained the Jewish contributions to the 'civilization of Christendom.' These were due to the position of the Jewish people as a 'nation of hybrids' within gentile society, resulting in a 'flexibility of aptitudes and capacities. ${ }^{40}$ Roth was thus not alone in his endeavor to counter anti-Semitism with the idea of the Jewish contribution to civilization: his bibliography attests to the amount of works that had appeared during the first decades of the 2oth century on this idea by, among others, Joseph Jacobs, Laurie Magnus, and Mordecai Kaplan. ${ }^{41}$

In 'The Jewish Contribution to Arab Culture,' Yallouz directs the gaze not to European Christendom and civilization and the Jewish place therein, but

$36 \quad$ Roth, The Jewish Contribution, xiii.

37 Roth, The Jewish Contribution, $\mathrm{x}$.

38 Roth, The Jewish Contribution, xiii.

39 The idea of the Jew as ultimately European resonates in the essay by Reinharz and Shavit on the complex and ambivalent Jewish perceptions of Europe during the 19th and 2oth centuries, which lead them to conclude that 'The Jews in Europe were (...), to one extent or another, European Jews': J. Reinharz and Y. Shavit, Glorious, Accursed Europe: An Essay on Jewish Ambivalence (Hanover and London 2010) 192.

40 T. Veblen, 'The Intellectual Pre-Eminence of Jews in Modern Europe,' Political Science Quarterly 34, no. 1 (1919) 33-42, 35-37. Veblen expressed these ideas in response to the rise of the Zionist movement. He expected that the realization of the Zionist project would result in national and intellectual isolation (and in that sense a new Ghettoization), ending the intellectually productive Jewish traits of skepticism and flexibility in the gentile world.

41 Roth, The Jewish Contribution, 369-370. D. Biale argues that the Jewish contribution to civilization discourse in the U.S. represents a trajectory that differs from the discourse in Europe. Mordecai Kaplan's book Judaism as Civilization, he shows, was written from the rather 'safe' confines of America, and contains not so much an apologetic discourse, but rather an attempt to reconcile rivaling conceptualizations of Jews as religion, people, and culture under the rubric of civilization: D. Biale, 'Louis Finkelstein, Mordecai Kaplan, and American "Jewish Contributions to Civilization", in Cohen and Cohen, eds., The Jewish Contribution, $185^{-197 .}$ 
to the past and present Arab-Islamic world and the relations between Arabs and Jews as Semitic peoples. His historical tour of Arab-Jewish cultural pride starts with the jāhiliyya, denoting pre-Islamic Arab society. He discusses the 'Arab-Jewish' tribes on the Arabian Peninsula and their literary contributions, in particular the Jewish poets exemplified by the figure of al-Samaw'al b. 'Ādiyā. The latter, who had attracted the interest of German-Jewish scholars a century earlier, ${ }^{42}$ held legendary status in Arab culture as a symbol of loyalty (according to the proverb 'more loyal than al-Samaw'al' [afwā min al-Samaw'al]). Amongst Yallouz's Jewish contemporaries in the Arab world, al-Samaw'al was popularized as a modern day example of Jewish loyalty. ${ }^{43}$ Yallouz underlines that the Arab-Jewish tribes on the Peninsula were original Arab tribes, to be distinguished from the Arabized tribes, and credits the former for the spread of monotheism and their religious values amongst the Arabs.

The latter idea echoes the European Jewish scholarly tradition on the topic of Jewish influence on Islam, which Abraham Geiger's Was hat Mohammed aus dem Judenthume aufgenommen? (1833) is held to have inaugurated. ${ }^{44}$ Yallouz and his fellow writers often expressed ideas and topoi that belong to the (diverse) tradition of German Jewish scholarship on Islam. Their engagement with European scholarship and orientalist tropes was not always explicit; as nationalist popular writers, they were often preoccupied with origins and authenticity. The scholarship was not only available to them through their encounters with Jewish scholars, such as the by al-Shams's editor muchadmired orientalist Avraham Shalom Yahuda (1877-1951). European and German Orientalist scholarship was widely read, appropriated, and criticized by Egyptian intellectuals, and the Egyptian University hosted a large number of European orientalists. ${ }^{45}$

Yallouz's narrative continues with the expansion of the Islamic empire. During the Abbasid Caliphate, he writes, the Arabic language was 'corrupted' by grammatical mistakes and distortion as a result of the non-Arab peoples

42 Heinrich Graetz discussed 'Samuel,' 'the most celebrated poet of Arabia in the time before Mahomet' in the third volume of his Geschichte der Juden (1853) in a chapter on Jews on the Arabian peninsula: H. Graetz, History of the Jews (Philadelphia 1891) 68-71.

The Iraqi-Jewish journalist and poet Anwar Shā'ūl used the pseudonym Ibn Samawaal [son of Samaw'al] during the 1920s: R. Snir, 'From al-Samaw'al to Ibn al-Samaw'al: Modern Arab-Jewish Culture, its Historical Background and Current Demise,' Acta Orientala 67 (2006) 19-79; idem, Arab-Jewish Literature: The Birth and Demise of the Arabic Short Story (Leiden 2019) 1-2.

44 S. Heschel, 'The Rise of Imperialism and the German Jewish Engagement in Islamic Studies,' in O. Fraisse, ed., Modern Jewish Scholarship on Islam in Context: Rationality, European Borders, and the Search for Belonging (Berlin 2018) 61-91, esp. 68.

D.M. Reid, 'Cairo University and the Orientalists,' International Journal of Middle East Studies 19, no. 1 (1987) 51-57. 
now living under Islamic rule. This is when the merit of the Jewish scholars appeared, who maintained the Arab literary heritage (al-turāth al-'arabi $a l$-adabì) through their translations of Greek, Persian, and Syriac sciences into Arabic. Under the Fatimid rulers in Egypt, Yallouz notes, the focus of Jewish intellectual productivity in Arab culture shifted to science and philosophy. The final stage is the Andalusian Golden Age (al-'așr al-dhahabì) of poetic and intellectual productivity. Together with al-Samaw'al, the Andalusian Jewish poet Judah ha-Levi demonstrates, in Yallouz's view, 'the supremacy of Jews in both Arabic and Hebrew poetry. ${ }^{\prime 6}$ In al-Andalus, Jews further excelled in the translation of many works on medicine, astronomy, mathematics, and history, which Islamic scholars subsequently could refine and consult.

The role of the Jews in the development of monotheism, and as safeguards, translators, and transmitters of science to the Arabs, enabled the latter to reach their Golden Age. In Yallouz's narrative, Jews are thus credited with a triple contribution: to the rise of Islam, the development of Arab culture, and subsequently to (European) civilization. A question that emerges from this perspective on the Arab-Jewish past is whether the historical stages and topoi present a mutual Arab-Jewish renaissance, or one that ultimately confirms a Jewish source of Arab and European/universal civilizational rise. It seems that the latter idea dominates, as in his narrative the 'Arabs' are less active contributors, than builders on Jewish monotheism and knowledge, and profiting from the work of Jewish translators.

Yallouz's representation of al-Andalus contrasts with Roth's rather brief reflection on Jews in 'Moslem Spain,' for which he admittedly relied heavily on earlier accounts in Joseph Jacobs's Jewish Contributions to Civilization (1919) and chapters in Charles and Dorothea Singer's The Legacy of Israel (1927) ${ }^{47}$ Roth is obviously not primarily concerned with singling out Jewish contributions to Arab culture, nor the notion of the Jewish and Arab Semites, but rather the Hebraic heritage and Jewish assistance to European Renaissance through their transmission of Hellenic tradition via Arab-Islamic culture. In his view, the Jews in Muslim Spain served as intermediaries between the separated Greek, Arab, and Latin worlds, and were able to bridge these worlds by the Hebrew 'medium of intercourse' and their linguistic knowledge. ${ }^{48}$ 'From the truly catholic point of view,' Roth stated, 'the Jews were the only real Europeans. ${ }^{49}$

46 Al-'̄́lam al-Isrǟìli, 14 May 1943, 3.

47 Roth, The Jewish Contribution, $5^{2-57 .}$

48 Roth, The Jewish Contribution, 54.

49 Roth, The Jewish Contribution, 54. See also C. Roth, 'The Jew as a European,' Presidential Address delivered before the Jewish Historical Society of England (London 1938). 


\section{Rise and Decline}

In 'The Jewish Contribution to Arab Culture,' the periods of Mamluk and Ottoman rule are glossed over. Yallouz's neglect of these historical periods is in accordance not only with European scholarly (orientalist) notions of Ottoman rise and decline and the centralization and idealization of the period of 'Classical Islam,' but also the views of Arab Nahda intellectuals of this period on Arab-Islamic history who, operating in the same rise and decline paradigm, often presented Turkish (non-Arab) despotism and decadence as the source of Arab decline. ${ }^{50}$

The themes and topoi in Yallouz's article further show that he incorporated, at least to a large extent, a specific element of the Jewish contribution to civilization discourse: the 'Golden Age and Decline discourse' on Sephardic and 'Oriental' Jews. Since the 19th century, German-Jewish scholars had imagined the Jews of the medieval Islamic world, al-Andalus in particular, as the ideal type of the assimilated and emancipated Jew. The world of medieval Islam served here as the mirror image of European Christianity and anti-Semitism. ${ }^{51}$ This idea was accompanied by the notion of the decline of 'Oriental' Jews in the modern Arab world. The latter was also part and parcel of the mission civilisatrice of the Alliance Israélite Universelle, aimed at enhancing the level of the once flourishing, but now 'orientalized' and 'degraded' Jews of the East. ${ }^{52}$

50 On the process of de-Ottomanization in Egyptian historiography since the 189os, see Y. Di-Capua, Gatekeepers of the Arab Past: Historians and History Writing in TwentiethCentury Egypt (Berkeley and Los Angeles 20o9) 66-9o. See also G. Piterberg, 'The Tropes of Stagnation and Awakening in National Historical Consciousness. The Egyptian Case,' in J. Jankowski and I. Gershoni, eds., Rethinking nationalism in the Arab Middle East (New York 1997) 42-61.

$5^{1}$ See for a discussion of this narrative in explicit relation to the idea of the Jewish contribution to civilization D. Schroeter, 'From Sephardi to Oriental: The "Decline" theory of Jewish Civilization in the Middle East and North Africa,' in Cohen and Cohen, eds., The Jewish Contribution, $125^{-148}$. More general examinations of European (Jewish) narratives on Sephardic and Oriental Jews include J.M. Efron, 'Scientific Racism and the Mystique of Sephardic Racial Superiority,' Leo Baeck Institute Year Book 38 (1993) 75-96; idem, 'From Mitteleuropa to the Middle East: Orientalism through a Jewish Lens,' Jewish Quarterly Review 94, no. 3 (2004) 490-520; idem, German Jewry and the Allure of the Sephardic (Princeton 2016); I. Schorsch, 'The Myth of Sephardic Superiority,' Leo Baeck Institute Year Book 34 (1985) 47-66; S.E. Aschheim, The Modern Jewish Experience and the Entangled Web of Orientalism, Menasseh ben Israel Instituut Studies 4 (Amsterdam 2010); M. Cohen, 'The "Golden Age" of Jewish-Muslim Relations: Myth and Reality, in A. Meddeb and B. Stora, eds., A History of Jewish-Muslim Relations. From the Origins to the Present Day (Princeton 2013) $28-38$.

52 A. Rodrigue, Images of Sephardi and Eastern Jewries in Transition: The Teachers of the Alliance Israélite Universelle, 1860-1939 (Seattle 1993). See also the essay by E. Bar-Chen, 
The idealized notion of the Andalusian Muslim/Arab-Jewish Golden Age later 'travelled' to Palestine, where it was incorporated and transformed by cultural Zionist, as well as non-Zionist scholars of German-Jewish origin working at the recently established School of Oriental Studies at the Hebrew University. ${ }^{53}$

Yallouz witnessed in the history of Arab-Jewish 'Semitic' cooperation the formation of civilization (takwin al-hada àra) and its advancement, and situates his argument within debates on the rise and fall of civilizations. He discusses the 'contemporary idea' that the first civilization was established in one geographical zone, and from there spread to the rest of the world, and rose here and declined there, remaining unchanged in one place, being reorganized by neighboring rulers, raids, or translocation in another. He notes that the latter idea has transplanted prior notions of civilizations as comprised of cultures created by shared mentalities, and subsequently Darwinist theory. In contrast to other nations, Yallouz argues, the Arab and Jewish nations (umam) have remained closely tied over the ages due to their unity of race ('unșur), historical homeland (the Arabian Peninsula), and linguistic (Semitic), moral, habitual, and traditional proximity: 'The Arab and the Hebrew belong to the same race and homeland. No wonder that the Arabian Peninsula is the original cradle of the Semitic nations and their culture. ${ }^{54}$ Yallouz thus understood civilizations to be based on racial, geographic, linguistic, and cultural ties. Hence the title of his article should be explained by his understanding of Arab culture (thaqāfa) to be part of a (Semitic) civilization (haḍara or tamaddun) in which both Jews and Arabs as Semitic peoples had flourished. ${ }^{55}$ His account testifies to the ambivalent issue of race within the Nahda and Egyptian and Arab

including Rodrigue's commentary, in M. Brenner, V. Caron, and U.R. Kaufmann, eds., Jewish Emancipation Reconsidered: The French and German Models (Tübingen 2003) $111-128$.

53 H. Harif, 'The Orient between Arab and Jewish National Revivals:Josef Horovitz, Schelomo Dov Goitein and Oriental Studies in Jerusalem,' in Fraisse, ed., Modern Jewish Scholarship, 319-335. See also S.E. Aschheim, Beyond the Border. The German-Jewish Legacy Abroad (Princeton 2007).

54 Al-'Ālam al-Isrä̀ìli, 14 May 1943, 4.

55 A. Al-Azmeh holds that, during the latter part of the 19th century, the Arabic term thaqa $f a$ (culture) carried a strong association of German Bildung and intellectual and artistic life, while hadâra (civilization) was understood as a more general concept encompassing the entire life of a society: A. Al-Azmeh, 'Civilization, Concept and History of,' International Encyclopedia of the Social \& Behavioral Sciences: Second Edition (Oxford 2015) 719-724. For a general account of colonial civilizational discourse in the Ottoman and Arab world, see B. Schlaebler, 'Civilizing Others: Global Modernity and the Local Boundaries (French, German, Ottoman and Arab) of Savagery,' in B. Schaebler and L. Stenberg, eds., Globalization and the Muslim World: Culture, Religion, and Modernity (Syracuse 2004) 3-31. 
nationalist thought. ${ }^{56}$ The question of race amongst Arab intellectuals was a subset of civilizational thought, fostered by the 19th-century confrontation with European imperialism, and its accompanying search for golden ages in the past out of concern over civilizational positions in the present. ${ }^{57}$

\section{Reform and Revival}

Yallouz's historical narrative can hardly be disentangled from his political and cultural vision for Jewish life in the contemporary Arab world. His motivation to write about the Jewish contribution to Arab culture, he tells his readers in the article, sprang from discussions in Egyptian and Palestinian newspapers on the assumed 'remoteness' of eastern Jews (al-yahüd al-sharqiyyūn) from the cultural movement in the Arab world. He states that he does not want to delve into the reasons for this assumed 'remoteness', but rather seeks to underline the historical contributions of Jews to Arab culture, and hence to show that the current neglect stands in stark contrast to Arab-Jewish history. 58

In the early 1940s, however, the chief-editor of al-Shams, Saad Malki, continuously addressed the causes of the perceived ignorance (or social illness, as it was often called) amongst the Egyptian Jews and the Jews of the East more broadly, and the need for revival and reform. Malki perceived the deadlock $(j u m \bar{u} d)$ to be the result of Egyptian-Jewish cultural orientation to the West, and the ignorance of their own Jewish and Arab religious and cultural heritage. Malki, Yallouz, and the aforementioned Wahba were all involved in the establishment of a local reform society, jam 'iyyat al-ișlāh al-isrä'iliyya, that aimed at enhancing the cultural and intellectual level of Egyptian Jews and promoting the Arabic language in order to accomplish a Jewish nahda - awakening or revival. ${ }^{59}$ Between 1941 and 1942, Malki printed the first chapters of Kitāb al-hidāya ilā farāiid al-qulūb (Guidebook to the Duties of the Heart) by the 11thcentury Andalusian philosopher Bahya b. Paqūda in his newspaper. Paqūda was introduced to the readers as an example of Jewish integration (indimāj) into Arab-Islamic society, dedication to Arabism, and pride in the noble nature of the Arab Semitic race. ${ }^{60}$

56 O. El Shakry, The Great Social Laboratory: Subjects of Knowledge in Colonial and Postcolonial Egypt (Stanford 2007) 55-86.

57 Elshakry, Reading Darwin in Arabic, 86-91.

58 Al-'̄́lam al-Isrä'illī, 14 May 1943, 3.

59 Al-Shams, 15 June 1942, 3.

6o Al-Shams, 7 November 1941, 1. The introduction and the first part of 'Kitāb al-Hidāya ilā farāidi al-qulūb,' on the Unity of God, were published in al-Shams between November 
Yallouz, as well as his fellow Egyptian-Jewish writers and amateur historians operating in the same societies, generally held middle class jobs as teachers, doctors, and translators while working in their evening hours on comparisons between the Semitic languages, Judaism and Islam, histories of Arab-Jewish relations, and popularizing articles on these themes. Their extensive contacts in the Egyptian intellectual and academic context, ${ }^{61}$ in particular the then recently established universities in Cairo and Alexandria, as well as the Hebrew University, and their frequent back-and-forth travels to Palestine, provided the intellectual climate that nourished their ideas. The group of al-Shams's writers specifically followed the recently established School of Oriental Studies at the Hebrew University. Many of the school's founders were proponents of the cultural and political need for Arab-Jewish rapprochement, and to this end turned to the useful past of Arab-Jewish relations, and some to the related concept of Semitism, and ideas on Semitic brotherhood, race, and civilization. ${ }^{62}$

Yallouz did not perceive the Jewish contribution to Arab culture to be solely a thing of the past. He perceived contemporary Jewish scholars of Islam, the Arab world, and the Semitic languages (including himself, perhaps) to be continuing the work of their medieval coreligionists, although (strangely, and almost ironically) he only mentions European Jewish scholars in this regard:

1941 and May 1942. The transcript was based, with only minor deviations, on the 1912 Arabic transliteration of A.S. Yehuda. Biblical passages in Yehuda's edition are in Hebrew, whereas in al-Shams these have been translated into Arabic. On A.S. Yehuda and his works, see Y. Evri, 'Translating the Arab-Jewish Tradition: From al-Andalus to Palestine/ Land of Israel,' Essays of the Forum Transregionale Studien 1 (Berlin 2016).

61 The activities of the Société d'études historiques juives d'Egypte, of which Yallouz served as secretary, demonstrate these contacts. In 1935, the society organized the celebrations at the Cairo Opera House of the 8ooth anniversary of Maimonides's birth, in cooperation with scholars from the Egyptian University, including the professor of Islamic Philosophy Muștafa 'Abd al-Rāziq.

62 H. Harif underlines that the department's representatives, though sharing an interest in Arab-Jewish relations and underlining the importance of studying the 'Orient,' cannot be said to present a singular intellectual and political trend. Shelomo D. Goitein and his former teacher Josef Horovitz, the latter a non-Zionist - though involved in the School of Oriental Studies and Brit Shalom - represent different political and intellectual trajectories, in particular on the Zionist 'cultural question.' Horovitz, Harif shows, was a proponent of the idea of a Semitic brotherhood between Arabs and Jews, which he perceived to be fundamental for a regional solution to Arab-Jewish alienation. He further held the view that the Arabian Peninsula was the original cradle to the Semitic peoples. Goitein, however, rejected the idea of a Semitic race overall (in his later work Jews and Arabs. Their Contacts through the Ages [New York 1955] he called it a 'pseudo-scientific myth,' 21.) as well as the idea that the Semites originated from Arabia. See Harif, 'The Orient between Arab and Jewish National Revivals.' 
With the cooperation of the Jews with the Arabs, the Semitic race carried the banner of general human thought, and transported the Arabic sciences to Europe. Until now, the Jews continue to be in earnest about the translation of Arabic literature, the history of Islam and its philosophy, the civilization of the Arabs in every respect, and the comparison of the Semitic languages. Amongst these contemporary scholars, we recall Salomon Reinach, Théodore Reinach, Levy ${ }^{63}$ and others. ${ }^{64}$

Despite this historical continuum, Yallouz did not refute the idea that the contemporary Jews of the East were in a state of decline and ignorance. Their revival was in the hands of the Jewish youth:

How nice it would be if our Jewish youth in the East would turn to this heritage that our worthy ancestors have left us, so that the old is connected to the new, and the Jews participate in the contemporary literary awakening. Why not be alongside Shawqī, Ḥāfiẓ, Muțrān, al-Rāfici and other intellectuals? Why would there not be alongside Ṭāhā Ḥusayn, al-Māzinī, Haykal, Taymūr, and al-Ḥakīm ${ }^{65}$ Jewish historians performing their duty towards the East, alongside the few whose names have finally appeared on the horizon?66

\section{Conclusion: A Globalizing Discourse}

The Jewish contribution to civilization as an idea and discourse has received scholarly attention primarily in the context of Europe and the U.S. ${ }^{67}$ No explicit assessment of this discourse (part of course of the history of Jewish and Christian apologetics) has been made beyond Western contexts, and how it was transmitted to, and transformed within non-Western and colonial

63 He might refer here to Reuben Levy, Oxford professor of Persian Literature and Islamic history, and author of A Baghdad Chronicle (1929) and The Sociology of Islam (1931-1933). The French brothers Salomon Reinach (1858-1932) and Théodore Reinach (1860-1928) were both archeologists.

64 Al-'̄lam al-Isrǟàlī, 14 May 1943, 5.

65 He refers here to Aḥmad Shawqī (1868-1932), Ḥāfiz Ibrahīm (1872-1932), 'Abd al-Raḥmān al-Rāfi i (1889-1966), Ṭāhā Ḥusayn (1889-1973), Ibrahīm 'Abd al-Qādir al-Māzinī (18891949), Maḥmūd Taymūr (1894-1973), Muḥammad Ḥusayn Haykal (1888-1956), and Tawfīq al-Ḥakīm (1898-1987), all prominent Egyptian intellectuals and literati. Khalīl Muțān (1872-1949) was a Lebanese poet who lived in Egypt.

66 Al-'̄lam al-Isrä̀ilì, 14 May 1943, 5.

67 Cohen and Cohen, eds., The Jewish Contribution. 
contexts. ${ }^{68}$ The field of modern Jewish history in the Middle East has recently witnessed a shift from the modernity-impact paradigm to agency and creative responses to colonialism. In line with this development, I have examined in this article how the colonial rise and decline model on 'Oriental' Jewry intersects with the Jewish contribution to civilization discourse in the Middle East trough popular appearances of this discourse amongst Jewish writers of Arabic.

The present case study on the Egyptian-Jewish writer and translator Alfred Yallouz shows that he appropriated the rise and decline narrative on Oriental Jewry on his own terms. What distinguishes the rise and decline narrative of Yallouz and his fellow reformer-writers Wahba and Malki from the colonial missions of European Jews aimed at civilizing their co-religionists in the East, was not the idea that the latter were in need of regeneration, but the direction which this upward movement should take. While both narratives agreed on a general state of decline and need for awakening, European Jewish efforts generally aimed at emancipating, and ultimately westernizing the 'Oriental' Jews through education, while Yallouz and his fellow writers criticized the cultural orientation of Jews in the Arab world to Europe, and wanted to restore the links with their Arab-Jewish intellectual and spiritual heritage.

Moreover, my analysis of Alfred Yallouz's appropriation shows that the transmission of the Jewish contribution discourse to Jews in the Middle East, and its incorporation in popular debates, should not be interpreted as simply a response to the presence of 'anti-Semitism' in the Arab world in any European sense. Rather, the translation in al-Shams and the surrounding Arabic discourse on the Jewish contribution coincided with regional intellectual debates on European anti-Semitism. This debate also included the fear of an extension of Nazi anti-Semitism in the Middle East and the targeting of the Semitic peoples of the 'East,' but more often it was embedded in national and regional processes of social reform and national reorientation that had followed the end of the Ottoman Empire. ${ }^{69}$

68 Daniel Schroeter discusses two counter-narratives to the rise and decline model. The first challenges the idea of Islamic tolerance by presenting the 'oriental' Jews as victims of persecution and anti-Semitism. The second is opposed to the first, and is exemplified by Ammiel Alcalay's post-Zionist notion of 'Levantine Culture' characterized by Arab-Jewish crossover. This model does not include a decline period, but extends the idealized past into modern times: Schroeter, 'From Sephardi to Oriental,' 145-146.

69 Recent scholarship on responses to Fascism and Nazism in the Arab world that has made extensive use of Arabic source materials is collected in I. Gershoni, ed., Arab Responses to Fascism and Nazism: Attraction and Repulsion (Austin 2014); F.R. Nicosia and B.A. Ergene, eds., Nazism, the Holocaust and the Middle East: Arab and Turkish Responses (New York 2018). 
Whereas Roth's idea of the Jewish contribution to civilization evolved in the explicit context of European and Nazi anti-Semitism, Yallouz's narrative should be understood first and foremost within regional cultural debates: the position of Jews in Arab society, the attempts of a regional network of Jewish intellectuals to promote Jewish and Zionist integration in the 'Arab East,' as well as the intra-Jewish cultural struggle between Sephardic and Ashkenazic Jews in Palestine and the wider region that was also premised on an East-West binary. Scholars have noted that the period of the Arabic Nahda witnessed an increasing interest in Jews and Judaism. ${ }^{70}$ To read this intellectual interest in relation to the regional debates of Jewish writers and their identification with the Arab East provides a fruitful theme for further research, and the possibility to explore the trope of the Jewish contribution to civilization within Arab intellectual discourse at large.

Lastly, the Jewish contribution discourse in Arabic cannot be understood without reference to the history of European Jewish scholarship on Islam and the different trajectories of the idea of Arab-Jewish symbiosis. ${ }^{71}$ While the ultimately Eurocentric Jewish contribution discourse was never disentangled from (anti-Semitic) Europe, considering the juxtaposition of Semitism and anti-Semitism, it was expressed in a radically different context, and aimed at a specific audience: the regional Arab-Islamic majority culture in which Jews sought to integrate. Going beyond the intellectual confines of Jewish scholarship in Europe and Palestine, the above analysis of the contribution discourse in al-Shams and al-Ālam al-Isrä'illi thus adds a new, non-Western layer to the multifaceted notion of the Jewish contribution to civilization, an idea - broadly connected to the aim of political and cultural emancipation - that remains to be fully explored in its 'global' reach.

70 L. Levy, "The Nahḍa and the Haskala: A Comparative Reading of "Revival" and "Reform," Middle Eastern Literatures 16, no. 3 (2013) 300-316, esp. 310; J.M. Gribetz, "'Their Blood is Eastern": Shahin Makaryus and Fin de Siècle Arab Pride in the Jewish "Race,"' Middle Eastern Studies 49, no. 2 (2013) 143-161.

71 In Goitein's Jews and Arabs, 127, he wrote that he had originally intended to write a chapter on the topic of 'the contributions made by Arab-speaking Jewish scholars to the progress of science in the Middle Ages,' but felt that these had little to do with the relations between Jews and Arabs or Judaism and Islam, and referred to Cecil Roth's work on the former topic. He also mentions the attempts by 'Arab scholars' in the 1920s, though he does not specify whom, to demonstrate the Jewish 'service' (khidma) to Arab culture, which hints at a broader circulation of ideas on this topic. 